Article

\title{
Land Use and Land Cover Changes in the Owabi Reservoir Catchment, Ghana: Implications for Livelihoods and Management
}

\author{
Philip Antwi-Agyei ${ }^{1, * \mathbb{C}}$, Felix Kpenekuu ${ }^{1}$, Jonathan N. Hogarh ${ }^{1}$, Kwasi Obiri-Danso ${ }^{2}$, \\ Robert C. Abaidoo ${ }^{2}$, Erik Jeppesen ${ }^{3,4}{ }^{(D)}$ and Mathias Neumann Andersen $4,5(D)$ \\ 1 Department of Environmental Science, Kwame Nkrumah University of Science and Technology, \\ Private Mail Bag, University Post Office, Kumasi, Ghana \\ 2 Department of Theoretical \& Applied Biology, Kwame Nkrumah University of Science and Technology, \\ Private Mail Bag, University Post Office, Kumasi, Ghana \\ 3 Department of Bioscience, Aarhus University, Vejlsøvej 25, 8600 Silkeborg, Denmark \\ 4 Sino-Danish Centre for Education and Research, Beijing 100049, China \\ 5 Department of Agroecology - Climate and Water, Aarhus University, Blichers Allé 20, 8830 Tjele, Denmark \\ * Correspondence: pantwi-agyei.sci@knust.edu.gh
}

Received: 13 March 2019; Accepted: 27 May 2019; Published: 28 June 2019

\begin{abstract}
Reservoir catchments in Ghana have undergone significant changes in recent years with major implications for socio-economic development and local livelihoods. We studied land use and land cover changes and their impacts on livelihoods in the Owabi reservoir catchment from 1970 to 2014 using Landsat, ERDAS Imagine and Arc Geographic Information System (ArcGIS 10.2) software supplemented with participatory approaches including focus group discussions, key informant interviews and questionnaire surveys with 400 households. Our results showed that, since 1970, $24.6 \%$ of high-density forests and $15.8 \%$ of sparse forests have disappeared, while the built-up area has increased from $9.8 \%$ to $56.6 \%$. Additionally, the proportion of bare soil (areas that do not have vegetation cover due to forest clearing and other anthropogenic activities) has increased, while the areas of waterbodies have declined. We identified urbanisation and lack of community involvement in catchment management as the key factors driving the land cover changes that have adversely affected the livelihoods of the local fringe communities. This study highlights the threats from urbanisation to land cover changes and identifies the key drivers of land use change. For effective and sustainable management of natural resources, the local communities should be more actively involved in the decision-making process regarding the management of their individual catchments.
\end{abstract}

Keywords: urbanisation; sustainable development goals; West Africa; participatory methods; Geographic Information System; climate change; food security

\section{Introduction}

Population growth and an increasing demand for natural resources to meet developmental needs have led to an unprecedented destruction of global ecosystems [1,2]. According to the Intergovernmental Panel on Climate Change [3], anthropogenic activities have had many negative impacts on peoples' livelihoods through continuous alterations of land use and exploitation of natural resources, which in turn affect the natural environment and change the landscape. Studies of the effects of land use changes have often focused on socioecological systems both locally and internationally [4,5]. Land use is related to any human activity and intervention that affects the land [6,7]. Land use change refers to a move into a different land use or the intensification of an existing land use [8]. Changes in land use affect both biogeochemical cycles and energy fluxes and thereby also livelihoods [9], and this is of 
particular importance in sub-Saharan Africa where the majority of households depend on land-based activities for their living.

In sub-Saharan Africa, rural livelihoods are often adversely impacted by changes in land use and land cover [10]. The impacts of land use/land cover changes are often compounded by the reliance of rural households on agro-based livelihood activities that are significantly dependent on the climate. Studies have established that the livelihoods of many farming households will be detrimentally affected by the ongoing changes in climate and land use [11,12]. This could have serious implications for food and livelihood security $[13,14]$ in a region characterised by high levels of poverty and low levels of infrastructural development. "A livelihood comprises the capabilities, assets (stores, resources, claims and access) and activities required for a means of living" ([15], p.7). A household choice of livelihood strategy is influenced by the various environmental endowments (including land and labour) and entitlements (such as social protection) at its disposal $[16,17]$.

Access to safe drinking water has improved worldwide over the last decades. However, approximately one billion people still lack access to safe water. Surface water is negatively affected by human-induced environmental changes that threaten the attainment of Sustainable Development Goal (SDG) 6 of the 17 global goals set by the United Nations General Assembly in 2015 of providing universal access to clean water and sanitation by 2030 [18]. Currently, it is estimated that $40 \%$ of the world's population are experiencing water scarcity, a figure that is projected to increase with the rise of global temperatures as a consequence of climate change ([18], p.2]). Increasing temperatures closely linked to climate change could adversely affect the availability and quality of water resources, especially in developing countries such as Ghana [19].

Reservoirs and dams are critical for meeting the needs and use of water by the majority of Ghanaians, and one such important reservoir is the Owabi reservoir [20,21]. This reservoir was constructed in 1928, and together with the Barekese reservoir, it functions as the major source of drinking water for the residents of the Kumasi metropolis and its surroundings, supplying about 1 million gallons of drinking water per day. However, over the years, the catchment of the Owabi reservoir has been exposed to massive encroachment, which has negatively affected the size and water quality of the reservoir [22] and hampered its ability to provide water, thereby threatening the attainment of SDG 6. Moreover, the catchment includes the Owabi Wildlife Sanctuary, which is a Ramsar site under the Ramsar Convention of 1976 [23]. It is the only inland Ramsar site in Ghana and contains many important plant and animal species that need to be protected [24], thus providing important ecosystem services [25]. Despite the significance of the Owabi reservoir for the socio-economic development of Ghana, knowledge is limited about the extent to which changes in land use and land cover within its catchment have affected land-based livelihood strategies and led to land use alterations.

This study employed mixed-method participatory approaches to elucidate and understand key changes in land use and land cover and their repercussions on the livelihoods of the population in the Owabi catchment. More specifically, we sought to (i) identify the key land use and land cover changes in the catchment; (ii) establish the main factors influencing the land use and land cover changes; (iii) explore the implications of land use changes for livelihoods, and; (iv) determine the role of local communities in the management of the Owabi catchment. A deeper understanding of the interrelationship between land use and land cover changes and rural livelihoods in resource-poor communities is crucial for the decision-making processes regarding sustainable management of natural resources, ecosystem monitoring and the related livelihood dynamics [17,26].

In Ghana, complex land tenure arrangements govern land resource ownership, 78\% of the total land area being under the communal tenure [27]. Of the remaining $22 \%$, it is estimated that $20 \%$ is owned by the state, while the remaining $2 \%$ is held under dual ownership between the state and the customary owners [28]. It is also important to take into account that under the customary ownership, the land belongs to the social group and not the individual [27]. Such complex tenure has often presented challenges to livelihood security and climate change adaptation in many parts of Ghana [29]. 


\section{Materials and Methods}

\subsection{Study Area}

The Owabi catchment is located in the Atwima Nwabiagya District in the Ashanti Region of Ghana and lies between latitudes $6^{\circ} 47^{\prime} 3.32^{\prime \prime}-6^{\circ} 41^{\prime} 52.31^{\prime \prime} \mathrm{N}$ and longitudes $1^{\circ} 44^{\prime} 0.81^{\prime \prime}-1^{\circ} 37^{\prime} 53.04^{\prime \prime} \mathrm{W}$ (Figure 1). The study area shares common boundary with the Ofinso municipality to the north, the Amansie-West and Atwima Kwanwoma districts to the south, the Kumasi Metropolitan and Afigya Kwabre districts to the east and the Atwima Mponua district to the west. The Owabi catchment hosts the Owabi Wildlife Sanctuary and the Owabi reservoir, which was the only source of drinking water to the whole of Kumasi metropolis until 1969 when the Barekese dam was constructed. The Atwima Nwabiagya district is located in the wet semi-equatorial zone, with maximum rainfall ranges between $1700 \mathrm{~mm}$ and $1850 \mathrm{~mm}$ per annum [30]. Rainfall delivery is slightly bimodal. The major rainfall season covers the long period between March through to July and a minor season from August to November. The temperature ranges between $27^{\circ} \mathrm{C}$ in August and $31^{\circ} \mathrm{C}$ in March [30]. The vegetation has been strongly disturbed by human activities, depriving it of valuable plant and animal species and other forest products [30].

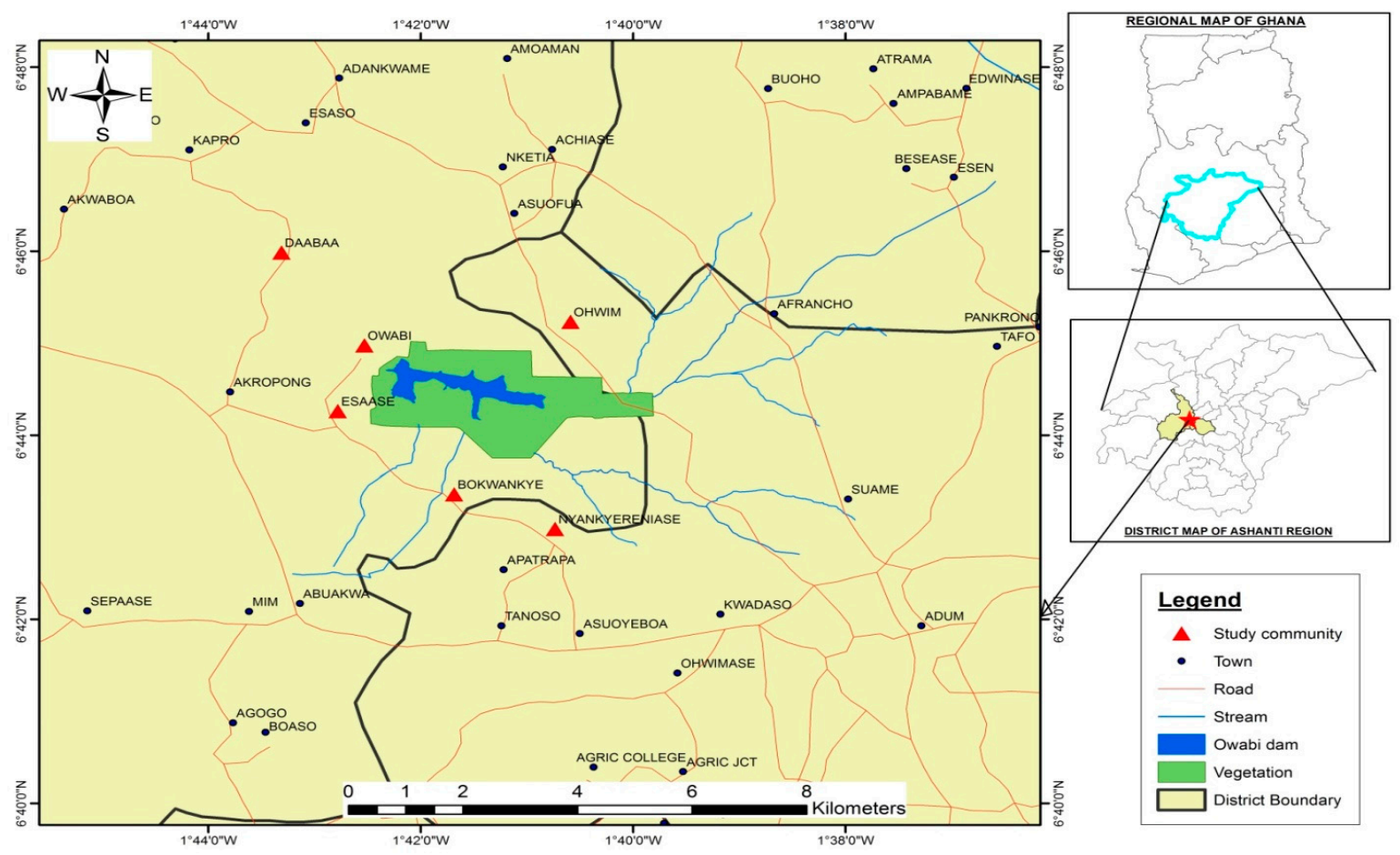

Figure 1. Map of the Owabi catchment showing the study communities.

Six towns-Bokwankye, Daabaa, Esaase, Nyankyereniase, Ohwim and Owabi-were selected for the study to cover almost every part of the cardinal direction and land-based livelihood activities characterising the catchment (Figure 1; Table 1). 
Table 1. Characteristics of the study communities.

\begin{tabular}{ccccc}
\hline Town & $\begin{array}{c}\text { Position } \\
\text { (Latitude and Longitude) }\end{array}$ & $\begin{array}{c}\text { Distance of Towns } \\
\text { to the Dam } \mathbf{( k m )}\end{array}$ & $\begin{array}{c}\text { Total } \\
\text { Households }\end{array}$ & $\begin{array}{c}\text { Number of } \\
\text { Respondents }\end{array}$ \\
\hline Bokwankye & $1^{\circ} 41^{\prime} 42^{\prime \prime} \mathrm{N}, 6^{\circ} 43^{\prime} 12^{\prime \prime} \mathrm{W}$ & 1.90 & 145 & 60 \\
Dabaa & $1^{\circ} 43^{\prime} 19^{\prime \prime} \mathrm{N}, 6^{\circ} 45^{\prime} 49^{\prime \prime} \mathrm{W}$ & 2.79 & $\mathrm{~N} / \mathrm{D}$ & 60 \\
Esaase & $1^{\circ} 42^{\prime} 48^{\prime \prime} \mathrm{N}, 6^{\circ} 44^{\prime} 05^{\prime \prime} \mathrm{W}$ & 1.15 & 187 & 62 \\
Nyankereniase & $1^{\circ} 40^{\prime} 44^{\prime \prime} \mathrm{N}, 6^{\circ} 42^{\prime} 49^{\prime \prime} \mathrm{W}$ & 2.91 & 650 & 99 \\
Ohwim & $1^{\circ} 40^{\prime} 36^{\prime \prime} \mathrm{N}, 6^{\circ} 45^{\prime} 04^{\prime \prime} \mathrm{W}$ & 1.78 & 317 & 79 \\
Owabi & $1^{\circ} 42^{\prime} 33^{\prime \prime} \mathrm{N}, 6^{\circ} 44^{\prime} 49^{\prime \prime} \mathrm{W}$ & 0.57 & 18 & 40 \\
\hline
\end{tabular}

$\mathrm{N} / \mathrm{D}=$ no data available.

\subsection{Data}

The study combined participatory approaches with Landsat satellite images to establish the implications of land use and land cover changes for the livelihoods of the Owabi catchment. Land cover analyses of the catchment were carried out using ERDAS Imagine 10.1 software for the classification of 1970 Landsat Thematic Mapper (TM), 1990 Landsat Thematic Mapper (TM), 2010 Landsat Thematic Mapper (TM) and 2014 Landsat Enhanced Thematic Mapper (ETM+) images (Figure 1). Thus, the study covered a 44-year period to identify possible changes in land use and land cover changes triggered by the considerable changes in population and urbanisation rates in the study area. The satellite images were derived from an open source Satellite Imagery Database from the United States Geological Survey (USGS) website. A land cover and use spatial analysis was carried out using Arc Geographic Information System (ArcGIS 10.2) and ERDAS Imagine 10.1 software. In ERDAS Imagine, image band combinations were manipulated from the default natural colour band combination in the image drape viewer to effectively identify different land use types in the study area, and the findings were later verified by ground truthing (gathered information/image material related to real features on the ground) to generate an appropriate training sample dataset for supervised classification. To improve the visual interpretability of the satellite data for a particular application, image enhancement was performed on all the acquired scenes. Table 2 shows the various land use and land cover classifications used in this study.

Table 2. Description of land use/land cover classification schemes used in this study.

\begin{tabular}{ll}
\hline \multicolumn{1}{c}{ Land Use Change } & \multicolumn{1}{c}{ Description } \\
\hline Waterbodies & $\begin{array}{l}\text { Waterbodies in the catchment area that empty into the Owabi reservoir. } \\
\text { These waterbodies include rivers, streams and reservoirs. }\end{array}$ \\
High-Density Forest & $\begin{array}{l}\text { Very active dense shrub vegetation, which looks greenish even in the dry season due } \\
\text { to high moisture content. } \\
\text { Sparse Forest }\end{array}$ \\
Built-Up & $\begin{array}{l}\text { Forest made up of sparingly scattered trees of all types and ages within the catchment. } \\
\text { activities or natural factors. }\end{array}$ \\
Farmlands & $\begin{array}{l}\text { Lands used for the cultivation of crops. } \\
\text { Land covered with sand or gravel. It has limited ability to support life and } \\
\text { Bare Soil }\end{array}$
\end{tabular}

Enhancement techniques were used together with classification techniques to extract features for the study catchment area, locating areas and objects on the ground and deriving useful information from the images. Furthermore, use of enhancement techniques to visually interpret the images helped optimise the complementary capabilities of the processing. Classification was done for 1970, 1990, 2010 and 2014 images to identify the various land cover and land use types and changes occurring over the years. Accuracy assessment of the classified imagery was performed to establish the level of accuracy of the classification. ArcGIS 10.2 was used for map composition as it increases the level of accuracy of the land use change determined from the image. 


\subsection{Methods}

In total, 400 household interviews were conducted in the six communities between February and June 2016. The interviews involved the answering of questionnaires containing close-ended questions supplemented with a few open-ended questions. A stratified sampling approach based on socio-economic characteristics such as age, gender and social standing was used to select the households for the interviews that were conducted face-to-face to better appreciate their responses and to probe further for clarifications. Accordingly, the questions were read out in the local language (Asante Twi) to allow the respondents to answer the questions appropriately. The interviews were conducted in the homes or any other place convenient for the respondents. The questionnaires focused on key variables such as socio-demographics, land use types (what they use their land for), household livelihood activities and diversification and community participation in resource management.

Focus group discussion (FGD) is an exchange of views and opinions by participants with detailed knowledge of the topic of interest. Ten such FGDs were conducted with participants selected based on demonstration of in-depth agro-ecological knowledge about the selected communities. The selection of participants for the focus groups was also based on the need to include different socioeconomic groups, including men, women, young people, traditional authorities as well as local-level unit committee and assembly members. Each FGD lasted between 45 minutes and 2 hours and consisted of between 7 and 15 members to ensure easy moderation of the discussion by the researchers. The discussions in the focus groups were recorded with the consent of participants and later transcribed.

Additionally, oral narratives were collected from focus group participants who demonstrated appreciable agro-ecological knowledge. The oral narratives were used to reconstruct livelihood histories [31] in order to explore and capture how various livelihoods have evolved within the study communities. The purpose of using the multiple-approach strategy was to provide triangulation, thereby solidifying the veracity of the findings of our research. The mixed-method approach provided a better understanding of the drivers of land use change from different perspectives whilst simultaneously providing an opportunity to appreciate the synergies and the contradictions in driving factors that may not be revealed by a single method [6].

\subsection{Data Analysis}

Quantitative data were analysed using descriptive statistics in IBM SPSS Software Version 23 and Microsoft Excel Software [32]. Qualitative data were analysed thematically to determine the key themes emerging from the FGDs. To establish the significance of involving fringe communities in managing the Owabi reservoir as well as construct livelihood activities, we used Chi-square analysis.

\section{Results}

\subsection{Land Use Change Analysis of the Owabi Area in 1970, 1990, 2010 and 2014}

In 1970, high-density forest was the dominant land cover class, occupying an area of 4203.4 ha $(53.3 \%)$ situated north, south, east and west within the Owabi reservoir catchment (Figure 2; Table 3). The second-most important class was sparse forest with 1963.8 ha $(24.9 \%)$, followed by built-up area with a coverage of 769.6 ha $(9.8 \%)$ (Figure 2$)$. 


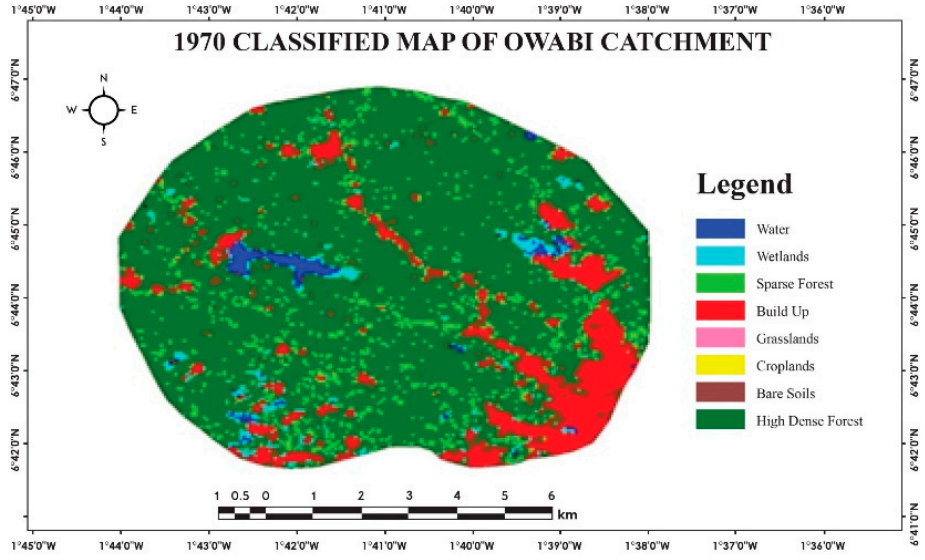

(a)

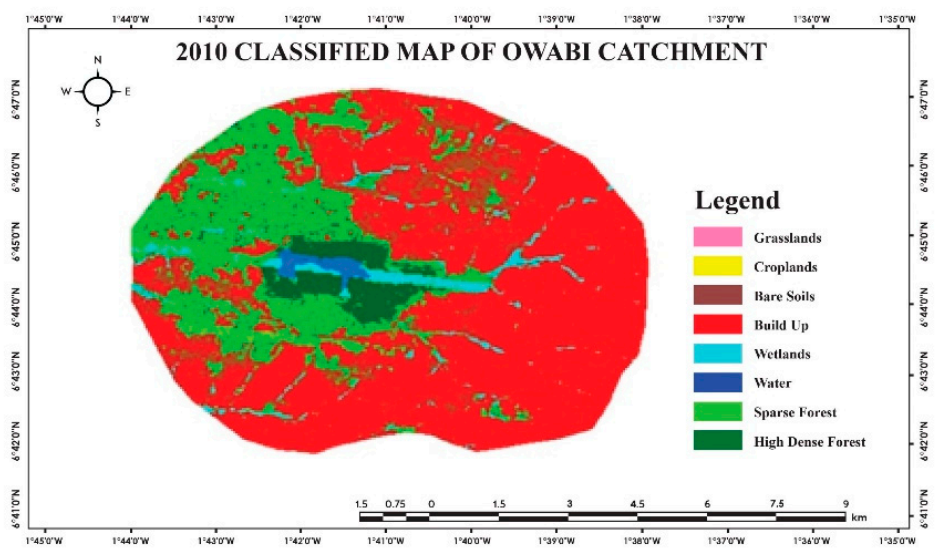

(c)

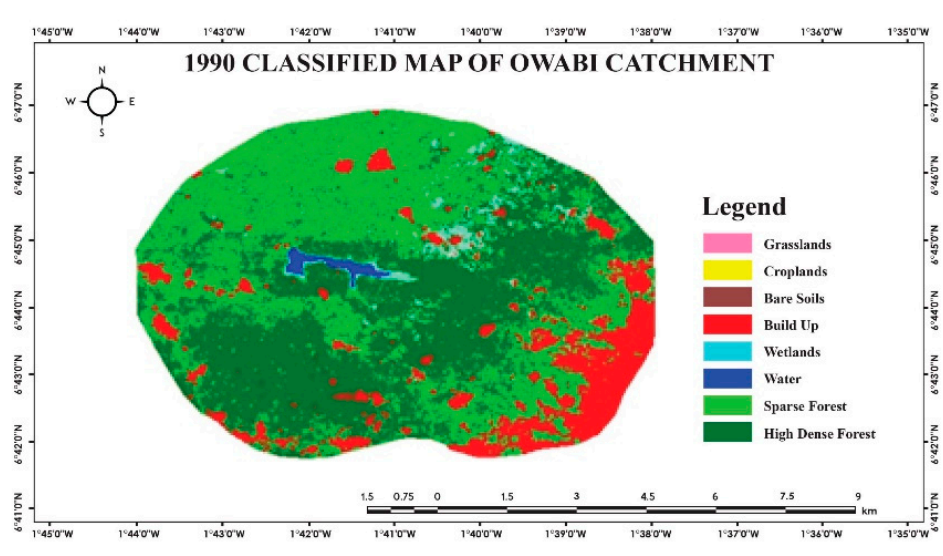

(b)

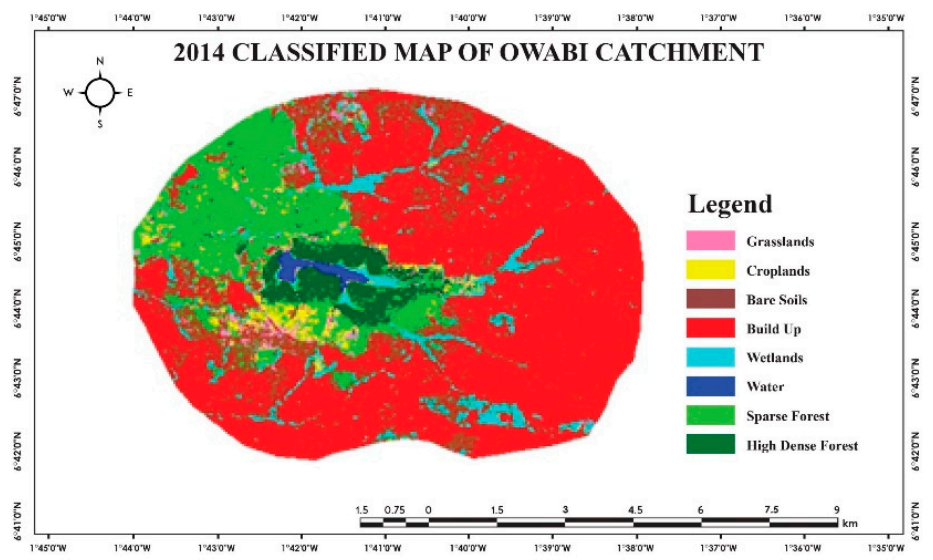

(d)

Figure 2. Classified maps of the Owabi catchment for 1970 (a), 1990 (b), 2010 (c) and 2014 (d). 
Table 3. The spatial extent of land use change after classification (ha).

\begin{tabular}{ccccc}
\hline \multirow{2}{*}{ Class Name } & \multicolumn{4}{c}{ Area (ha) } \\
\cline { 2 - 5 } & $\mathbf{1 9 7 0}$ & $\mathbf{1 9 9 0}$ & $\mathbf{2 0 1 0}$ & $\mathbf{2 0 1 4}$ \\
\hline Built-Up & $769.6(9.8)$ & $1250.3(15.6)$ & $4141.8(52.5)$ & $4465.7(56.6)$ \\
High-Density Forest & $4203.4(53.3)$ & $3856.8(48.9)$ & $468.3(5.9)$ & $413.91(5.3)$ \\
Croplands & $245.7(3.1)$ & $231.7(2.9)$ & $120.7(1.5)$ & $342.3(4.3)$ \\
Bare Soils & $76.8(1.0)$ & $163.6(2.1)$ & $355.6(4.5)$ & $650.9(8.3)$ \\
Grasslands & $197.9(2.5)$ & $223.5(2.8)$ & $810.2(10.3)$ & $374.4(4.8)$ \\
Wetlands & $327.8(4.2)$ & $367.7(4.7)$ & $490.2(6.2)$ & $473.6(6.0)$ \\
Waterbodies & $101.8(1.3)$ & $97.34(1.2)$ & $82.6(1.1)$ & $56.4(0.7)$ \\
Sparse Forest & $1963.8(24.9)$ & $1695.8(21.5)$ & $1417.22(18.0)$ & $1109.5(14.1)$ \\
\hline Total Area & $7886.7(100.0)$ & $7886.7(100.0)$ & $7886.7(100.0)$ & $7886.7(100.0)$ \\
\hline
\end{tabular}

The 1990 supervised classified map showed a substantial reduction of land cover change compared with 1970 for the different land cover classes, except built-up areas, wetlands and grasslands (Figure 2). High-density forest occupied 3856.8 ha (48.9\%) and wetlands approximately 367.7 ha $(4.7 \%)$, the latter being situated in the north-eastern zone of the catchment and in the central part of the water reservoir. Croplands occupied a minor area of 231.4 ha $(2.9 \%)$, which was randomly distributed within the catchment. Waterbodies occupied 97.3 ha (1.3\%) (Figure 2).

The 2010 supervised Landsat map showed substantial changes relative to the previous 20-year period with built-up areas occupying 4141.8 ha (52.5\%), followed by sparse forest with 1417.2 ha $(18.0 \%)$ in the north-western and south-western parts of the Owabi catchment. Patches of sparse forest occurred in the northern zone of the study area. Grasslands occupied 810.2 ha (10.3\%), spread across the entire study area. The area of croplands decreased to 120.7 ha (1.5\%) and was situated at the fringes of the study area.

The 2014 supervised Landsat classified map of the study area revealed that built-up areas occupied 4465.7 ha, representing $56.6 \%$ (i.e., more than half of the total land area). Sparse forest also occupied a significant portion of the land (1109.5 ha or $14.1 \%)$.

\subsection{Land Use Change Accuracy Assessment for 2014}

An accuracy land use assessment was elaborated for the 2014 map and presented in the form of an error matrix, accuracy totals and a kappa statistic (Table 4). An overall kappa statistic of 0.77 (kappa coefficient) was achieved. The highest user accuracy of all the land use changes was obtained for waterbodies, built-up areas, sparse forest and high-density forest with a value of $86.7 \%$ (lowest $60 \%)$. As for producer accuracies, grasslands $(62.5 \%)$ showed the lowest and waterbodies the highest values (Table 4).

Table 4. Accuracy assessment for the study period

\begin{tabular}{ccccccc}
\hline Class Name & $\begin{array}{c}\text { Reference } \\
\text { Totals }\end{array}$ & $\begin{array}{c}\text { Classified } \\
\text { Totals }\end{array}$ & $\begin{array}{c}\text { Correct } \\
\text { Number }\end{array}$ & $\begin{array}{c}\text { Producer's } \\
\text { Accuracy (\%) }\end{array}$ & $\begin{array}{c}\text { User's } \\
\text { Accuracy (\%) }\end{array}$ & Kappa \\
\hline Waterbodies & 26 & 30 & 26 & 100.0 & 86.7 & 0.85 \\
Bare Soils & 25 & 30 & 18 & 72.0 & 60.0 & 0.55 \\
Built-Up & 38 & 30 & 26 & 68.4 & 86.7 & 0.84 \\
Sparse Forest & 32 & 30 & 26 & 81.3 & 86.7 & 0.85 \\
High-density Forest & 29 & 30 & 26 & 89.7 & 86.7 & 0.85 \\
Grasslands & 32 & 30 & 20 & 62.5 & 60.0 & 0.62 \\
Croplands & 29 & 30 & 23 & 79.3 & 72.1 & 0.76 \\
Wetlands & 29 & 30 & 25 & 86.2 & 81.7 & 0.82 \\
Total & 240 & 240 & 190 & & & \\
\hline
\end{tabular}




\subsection{Land Cover Change and Conversion Analysis within the Owabi Catchment from 1970 to 2014}

Analysis of land cover change and conversion within the Owabi catchment was conducted for the period 1970 to 2014 (Table 5). For about 16\% of the area, there was no change in land cover type for the period 1970-2014. Significantly, 1939.7 ha, representing $24.6 \%$ of the high-density forest cover, were converted to built-up area, as were 1244.5 ha $(15.8 \%)$ of sparse forest.

Table 5. Land cover conversions from 1970 to 2014 (ha).

\begin{tabular}{|c|c|c|c|c|c|c|c|c|c|c|}
\hline \multirow[b]{2}{*}{ LULC } & \multicolumn{10}{|c|}{2014} \\
\hline & & Built-Up & $\begin{array}{l}\text { High- } \\
\text { Density } \\
\text { Forest }\end{array}$ & Croplands & $\begin{array}{l}\text { Bare } \\
\text { Soils }\end{array}$ & Grasslands & Wetlands & Water & $\begin{array}{l}\text { Sparse } \\
\text { Forest }\end{array}$ & $\begin{array}{c}\text { Total } \\
\text { Area } \\
\text { (Ha) }\end{array}$ \\
\hline \multirow{6}{*}{1970} & Built-Up & 692.5 & 13.9 & 10.7 & 19.9 & 12.6 & 2.6 & 0.8 & 16.6 & 769.6 \\
\hline & $\begin{array}{l}\text { High-Density } \\
\text { Forest }\end{array}$ & 1939.7 & 367.6 & 198.6 & 442.3 & 187.5 & 191.3 & 9.8 & 866.6 & 4203.4 \\
\hline & Grasslands & 217.3 & 7.5 & 7.3 & 12.5 & 17.7 & 1.2 & 0.8 & 23.8 & 197.9 \\
\hline & Wetlands & 175.8 & 8.3 & 2.1 & 1.5 & 5.1 & 28.1 & 8.2 & 26.7 & 327.8 \\
\hline & Waterbodies & 58.5 & 2.8 & 8.7 & 7.2 & 6.7 & 11.0 & 39.3 & 12.7 & 101.8 \\
\hline & Sparse Forest & 1244.5 & 7.6 & 93.9 & 67.5 & 87.3 & 49.2 & 0.1 & 85.9 & 1963.8 \\
\hline \multicolumn{2}{|c|}{ Total Area (ha) } & 4465.7 & 413.9 & 342.3 & 650.9 & 374.4 & 473.6 & 56.4 & 1109.5 & 7886.7 \\
\hline
\end{tabular}

\subsection{Socio-Demographics of the Questionnaire Respondents}

Out of the 400 questionnaire respondents, $45 \%(n=180)$ were men. The majority of the respondents were within the working age and thus capable of undertaking economically viable activities to make a living. About $38 \%$ of the respondents were between 40 and 59 years and an appreciable number belonged to the age class 19-39 ( $\mathrm{n}=151 ; 37.8 \%$ ) (i.e., "young"). Education is an important livelihood indicator, and about $69 \%$ of the respondents had some formal education (Appendix A Table A1).

\subsection{Livelihood Activity in the Owabi Catchment}

Various livelihood activities in the catchment were identified (Table 6). Petty trading (i.e., buying and selling of groceries and other goods) was the core activity and essential for sustaining the livelihood of the households $(\mathrm{n}=125,31.3 \%)$, followed by salaried work $(22.0 \%)$ and food crop production (21.5\%). Other livelihood activities included tailoring, hairdressing, masonry and other small-scale menial jobs, making up about $16 \%$ of livelihood options in the catchment. The fringe communities depend on the latter because of the change in traditional land use types, affecting their land-based livelihood activities. The change to built-up land is the most dominant type of conversion altering people's livelihoods. This was made clear during the FGDs when a male discussant said: "Most of our farmlands were taken due to the construction of the reservoir and this has affected our agro-based livelihood activities." (Focus group participant, Ohwim, 2016). 
Table 6. Livelihood activities in the Owabi catchment.

\begin{tabular}{|c|c|c|c|}
\hline \multirow{2}{*}{ Parameters } & \multicolumn{2}{|c|}{ Sex } & \multirow{2}{*}{ Total } \\
\hline & Male & Female & \\
\hline \multicolumn{4}{|c|}{ Main source of livelihood activity: $n=400$} \\
\hline Food crop & $42(10.5)$ & $44(11.0)$ & $86(21.5)$ \\
\hline Livestock & $13(3.3)$ & $8(2.0)$ & $21(5.3)$ \\
\hline Fishing & $14(3.5)$ & $1(0.3)$ & $15(3.8)$ \\
\hline Petty trading & $31(7.8)$ & $94(23.5)$ & $125(31.3)$ \\
\hline Salaried work & $45(11.3)$ & $43(10.8)$ & $88(22.0)$ \\
\hline Other & $35(8.8)$ & $30(7.5)$ & $65(16.3)$ \\
\hline Mean $=1.55$ & $\mathrm{SE}=0.025 ; \mathrm{X}^{2}=41.097$ & $\mathrm{df}=5 ; p$-value $=0.000$ & \\
\hline Total & $180(45.0)$ & $220(55.0)$ & $400(100.0)$ \\
\hline
\end{tabular}

Numbers in and outside parentheses are percentages and total counts, respectively. $X^{2}=$ Pearson Chi-square value and $\mathrm{SE}=$ standard error.

\subsection{Effects of the Owabi Reservoir on the Livelihoods within the Catchment}

This section examines the effects of land use changes resulting from the construction of the Owabi reservoir on people's livelihoods and the overall natural environment. The reservoir presents both constraints and opportunities for the local population around the outlying towns [33-35], and it has either improved or worsened the living conditions of the community dwellers. There was consensus among the focus group participants that the presence of the reservoir has negatively affected the livelihoods of the local communities as illustrated by the following characteristic remark:

The people in this community are farmers whose livelihoods depend primarily on agro-based activities, mainly crop production. The crops provide food for our families. Despite this, they took over our lands from our parents for the construction of the reservoir and today we cannot have lands for our farming activities (Focus group participant, Esaase, 2016).

Another participant stated:

How can you conduct meaningful agricultural activities without access to adequate land? Getting land for farming is extremely difficult in our community because of the Owabi reservoir and its catchment (Focus group participant, Esaase, 2016).

Another participant said:

Life is becoming unbearable in our community. The government took our lands for the construction of the Owabi reservoir and this has resulted in lack of farming lands. Because of this, most young people in our communities are not interested in farming (Key informant, Daabaa, 2016).

The key theme emerging from the FGDs was that farming households within the Owabi catchment think that the acquisition of land for the construction of the reservoir and the subsequent ban on agricultural activities within the catchment have had adverse impacts on their livelihoods. This is important because agro-based activities remain a key livelihood source in the catchment. The oral narratives of community members (see Table 7) provide evidence for the changing nature of livelihood opportunities within the catchment. 
Table 7. Oral narratives with selected households.

Oral narrative 1

Mr. Mensah, age 66, is the head of a, by local standards, well-to-do household of seven. Mr. Mensah is married and moved from the Greater Accra Region, Ghana, to Owabi in the 2000s. He works as a security guard to support his family, and to enhance the income he also cultivates food crops and rears poultry. Mr. Mensah's wife supplements the family's income with petty trading at the market. As a migrant to the area, Mr. Mensah stressed the difficulties in accessing fertile land for agricultural activities, as this is simply not available. Mr. Mensah explained that his household's livelihood is better today than it was 10 years ago due to regular remittances from his children and other relatives. Mr. Mensah stated: "My children send us money regularly, which makes our household less vulnerable". He enumerated some of the benefits of the Owabi reservoir and the reserve forest such as provision of water to Kumasi and its environs, including the catchment communities. Mr. Mensah reported that the local community is allowed to fish in the reservoir and pick wild food in the forest. In addition, the women can gather firewood in a regulated form. He therefore advised that the reservoir should be protected from encroachment from fringe communities.

\section{Oral narrative 2}

Mr. Ansah, age 63, lives with his wife and five children in Ohwim in a 5-bedroom roofed house in a, by local standards, rich household. Mr. Ansah is a native of Ohwim and has a Middle School Leaving Certificate. Mr. Ansah worked at the production unit of the Ghana Water Company in Owabi for about 30 years and supplemented the household's income with livestock and poultry rearing. His wife is a petty trader and sells second-hand clothes in the market. The household cultivates various crops on subsistence basis and the food crops are harvested for household consumption. Mr. Ansah and his wife have five grown-up children of whom only one child works, as a teacher in Kumasi. Mr. Ansah says that the challenge of feeding his family has increased because he seldom receives remittances from his unemployed children and he finds that life is more difficult today than it was ten years ago. Part of the problem is lack of access to farmland due to urbanisation. Commenting on the impact of the Owabi reservoir, Mr. Ansah mentioned the benefit of its provision of water to the communities within and outside the catchment. In addition, people are allowed to fish in the dam. He therefore expressed concern about the impact of the intense encroachment into the reservoir on the sustainability of the reservoir and the reserve forest. He pointed out that the encroachment is a protest to the government against the lack of compensation to landowners. The lack of land has affected household livelihoods, compelling them to venture into other non-sustainable activities such as driving, tailoring and masonry.

\section{Oral narrative 3}

Madam Dufie, age 46, is married with five children and has resided in Esaase for more than 26 years in a, by local standards, poor household. Madam Dufie was born in Atwima and later moved to Esaase with her husband. They made a living by poultry farming, but invasion of the farm by thieves disrupted their livelihood. The couple supplemented their income with growing of crops, but lack of access to land prevented them from continuing with this. Life, especially the raising of five children without a sustainable income, was-and remains-difficult until she got employment as a cook at a Senior High School. Madam Dufie's husband supplements their income with small-scale poultry rearing. Three of Madam Dufie's five children are grown-ups; two serve in the military as trainees and the third has just completed nursing school and seeks employment. The remaining two are still at school. "Currently, the household's only source of income is what I receive at the end of the month and my husband's irregular income from the small poultry farming," Madam Dufie said. She continued: "I have no reliable and sustainable alternative sources of income apart from my meagre salary and what my husband brings home from his poultry business, which is season dependent, to support the family. This means that any time the poultry business is out of season, my household is in serious trouble in terms of supplying food for the family. This problem is compounded by the fact that we still have to pay school fees for two of our children." Madam Dufie said that the construction of the reservoir has had two positive effects-the reservoir supplies water to the fringe communities and to Kumasi as a whole and the catchment communities are allowed to fish in the reservoir, which may help them to meet their economic challenges. In addition, the women are allowed to collect wild fruits, snails and firewood in the reserve forest under regulated conditions. However, according to Madam Dufie, the reservoir has also had a negative effect by the takeover of land from their original owners without any compensation, which has destabilised people's livelihoods in the catchment. 


\subsection{Community Participation in the Management of Natural Resources}

Of the respondents, $86 \%(n=345)$ said that they were not involved in the management of the reservoir, while $84 \%(n=337)$ indicated that they were not engaged in the management of the forest (Table 8). Only a few people were allowed to fish in the reservoir. The non-involvement of the community dwellers in the management of the community's natural resources is attributed to lack of technical know-how, absence of readily available job opportunities in the Owabi communities and the lack of compensation for the forced takeover of their lands to construct the reservoir, as revealed in the FGDs and interviews with key informants. During the FGDs, the respondents said that they were willing to participate in the management if the necessary training in resource use is provided.

Table 8. Communities' participation in the management of the Owabi reservoir.

\begin{tabular}{|c|c|c|c|c|c|c|c|}
\hline \multirow{2}{*}{ Parameters } & \multicolumn{6}{|c|}{ Community of Respondents } & \multirow{2}{*}{ Total } \\
\hline & Bokwankye & Dabaa & Esaase & Nyankyereniase & Ohwim & Owabi & \\
\hline \multicolumn{8}{|c|}{ Reservoir } \\
\hline Yes & $6(1.5)$ & $0(0.0)$ & $18(4.5)$ & $14(3.5)$ & $16(4.0)$ & $1(0.2)$ & $55(13.7)$ \\
\hline No & $54(13.5)$ & $60(15.0)$ & $44(11.0)$ & $85(21.2)$ & $63(15.8)$ & $39(9.8)$ & $345(86.3)$ \\
\hline Mean $=1.86$ & $\mathrm{SE}=0.017$ & $X^{2}=29.585$ & $\mathrm{df}=5$ & $p$-value $<0.001$ & & & \\
\hline \multicolumn{8}{|c|}{ Forest } \\
\hline Yes & $9(2.2)$ & $1(0.2)$ & $17(4.2)$ & $19(4.8)$ & $16(4.0)$ & $0(0.0)$ & $62(15.4)$ \\
\hline No & $51(12.8)$ & $59(14.8)$ & 45 (11.3) & $80(20.0)$ & $63(15.8)$ & $40(10.0)$ & $337(84.7)$ \\
\hline Mean $=1.85$ & $\mathrm{SE}=0.018$ & $X^{2}=30.916$ & $\mathrm{df}=10$ & $p$-value $=0.001$ & & & \\
\hline Total & $60(15.0)$ & $60(15.0)$ & $62(15.5)$ & $99(24.8)$ & $79(19.8)$ & $40(10.0)$ & $400(100)$ \\
\hline
\end{tabular}

Numbers in and outside parentheses are percentages and respondent counts, respectively. $\mathrm{X}^{2}=$ Pearson Chi-square value.

\section{Discussion}

Our study revealed that substantial changes in land use took place in the Owabi catchment from 1970 to 2014, mainly through the conversion of large areas of high-density and sparse forest to built-up area. This extensive transformation can be attributed to increasing urbanisation in the Kumasi metropolitan area, pushing settlements back. The population in many urban areas in sub-Saharan Africa has grown significantly due to rural-urban migration as a result of lack of employment opportunities and social amenities in the rural areas. Other studies have also identified urbanisation to be the key cause of land cover changes within forest reserves in Ghana [36,37]. In Namibia and Kenya, investigations have identified agricultural expansion, population growth increase and illegal logging as the key drivers of land use and land cover changes, with serious debilitating effects on peoples' livelihood activities [38].

The Owabi catchment is situated very close to the Kumasi metropolis where the demand for land for residential purposes and other activities is extremely high [39]. The greater urbanisation is linked to a major increase in population size; thus, in the Owabi catchment, the population has increased substantially-from 31,257 in 1970 to 143,348 in 2000 [39]. Ghana is quickly becoming urbanised [40] with the urban population being mainly concentrated in cities such as Accra and Kumasi. Population growth has been emphasised as a main driver of land use change, especially in developing countries [41,42]. Census data show that between 1984 and 2010, Kumasi's population increased with a growth rate of over $5 \%$ per annum [39], making it one of the fastest growing cities in Ghana [43] and implying an expansion of the built-up area [44]. The changes observed in the Owabi catchment are consistent with those observed in many studies conducted at national and regional levels in Ghana [6,41,45-47]. For example, using a mixed-method approach, Kleeman et al. [6] identified population growth as a major driver of land use and land cover changes in Ghana's Upper East region. Various anthropogenic activities, including agriculture, have led to encroachment of human settlements on forest lands, with devastating consequences for biodiversity [41]. Our results showed a 
massive reduction in forested areas. This corresponds with the results of other studies suggesting that forest areas in Ghana have undergone massive reduction [46]. The increased encroachment into forest areas and other protected areas including the Owabi reservoir may partly be attributed to government policies such as liberalisation of the forest reserves and the Structural Adjustment Program embarked upon in the 1980s and early 1990s, which allowed for the expansion of the timber industry [48].

Overall, a large population entails a higher demand for fuel wood and conversion of more agricultural land to human settlements to meet the growing feeding needs [49]. With a population projected to increase and the fast rate of urbanisation [39], the fragile Owabi catchment will without doubt continue to suffer from anthropogenic pressures. So far, the increased human population has resulted in shrinking of farmland areas. Increased production of food for consumption is undermined by rapid population growth, unequal land distribution, shrinking landholdings and widespread land degradation [50]. Due to lack of areas of agricultural expansion, the intensity of land use has increased, causing depletion of nutrients.

Anthropogenic activities such as illegal chainsaw logging and mining are principal drivers of the changing land structure and water resources in southern Ghana [51]. Small-scale illegal mining has contributed to the continuous degradation of Ghana's forests, leading to disappearance of vegetation, siltation and sedimentation of waterbodies [41], including the Owabi reservoir. Our findings confirmed the observation of increased intrusion upon the forest reserve by fringe communities, raising the question whether enforcement of rules and regulations by enforcing agencies should be applied as part of the management of the natural resources. Our findings also suggest that the lack of compensation to landowners has contributed to the gradual destruction of the forest in the catchment.

Alarmingly, our results showed a significant reduction in the extent of waterbodies in the period under consideration as a result of the land transformation in the catchment area. The reduced size of waterbodies has implications for the water safety for the surrounding communities and beyond as the Owabi reservoir provides drinking water to about 1 million people in the Kumasi metropolis and its surrounding communities. These findings corroborate those of previous studies suggesting that massive encroachment on the catchment has affected the quality of the water in the reservoir and its ability to continue to provide water [20,52] and support ecosystem services [25]. The growth of towns in developing countries has often led to encroachment on watercourses as new buildings are constructed, either legally or illegally. This has been a challenge for most cities across the sub-Saharan Africa [41].

In the focus group discussions, the participants reported that acquisition of previous farmlands within the catchment have had negative impacts on their livelihoods in that they were no longer available for agricultural production. This has serious consequences for livelihood security at the household level and for the study communities of which most are now engaged in non-farming activities.

In a situation where most farmlands are being converted to built-up area, as in today's Owabi catchment, diversifying non-agricultural livelihood activities can buffer against the negative impacts of land shortage and climate variability [53]. Livelihood diversification provides new opportunities for households that lack access to traditional-based livelihoods. This was the case for our study communities and the same pattern occurs in most parts of sub-Saharan Africa [53,54] and supports findings [55] that engagement in non-farm livelihood activities helps agrarian communities to overcome the pressures of the land use changes and climatic variations. Nonetheless, it is important that households are appropriately supported by regional and national policy makers in order not to engage in activities that will worsen their existing vulnerabilities [56].

Our study revealed a number of livelihood activities in the study communities. According to [30,39], some 14,528 (25.1\%) of the economically viable population in the Atwima Nwabiagya District were employed in the wholesale and retail sectors, followed by agriculture with 14,339 (24.8\%). Thus, the agro-based livelihood activity is undergoing a fast decline and is concentrated around the peripheral of waterbodies that feed the Owabi reservoir. This proximity of agriculture to waterbodies may lead to accumulation of nutrients, sediment and pesticides, resulting in siltation and eutrophication, which 
can affect aquatic life in the reservoir. Accordingly, several studies have reported elevated levels of nutrients in the Owabi reservoir $[20,23,52]$ as well as heavy pollution with faecal coliforms (coli) and faecal enterococci, posing significant health risks [20].

Our study revealed that the livelihoods of the fringe communities have been significantly impacted by the construction of the Owabi reservoir as well as by the ban on agricultural activities within the catchment. In general, climate variability, together with anthropogenic activities, has serious impacts on the livelihoods of rural agro-based communities in Ghana and sub-Sahara, driving environmental and socio-economic changes $[11,57,58]$. A likely explanation of the inability of households to sustain their livelihoods in the Owabi catchment, as reported in the interviews, is loss of farmlands, the lack of compensation to land owners and social inequality, leading to the deteriorating livelihoods in the catchment. Thus, it may be argued that a compensation scheme should have been instigated to support such diversification and that the economic resources could have been derived from levies on drinking water delivered from the reservoir. Such a scheme would have provided a fairer distribution of burdens and, on small scale, counteracted rural livelihood deterioration and urbanisation.

Our study further revealed that fringe communities were not actively involved in the management of the Owabi reservoir. Full involvement of communities at the local level is indispensable for ensuring sustainable and proper management of the natural resources [59]. The lack of involvement and lack of proper compensation have several implications for the present and future sustainability of the reservoir and the reserve forest within the study catchment. As argued by [60], successful planning and implementation of a project need to be discussed thoroughly with key stakeholders where economic externalities are not clearly outlined since lack of proper sorting of ownership issues in the planning phase will negatively affect the project's success. Our results provide similar evidence.

\section{Conclusions}

Our study employed a mixed-method approach to demonstrate the extent of various land use changes taking place in the Owabi catchment where a major reservoir provides water to people in the Kumasi metropolis and its surroundings. The study revealed that substantial areas of high-density and sparse forestlands were converted to built-up area from 1970 to 2014. The study further revealed that the proportion of bare soil (areas without vegetation cover due to anthropogenic activities) has increased, while the areas of waterbodies have declined. These changes have primarily been driven by urbanisation, lack of community involvement in the management of the catchment and lack of compensation for lands to landowners. The demand for land and land-based resources to support competing livelihoods and developmental activities in different parts of the catchment created by an increasing population has led to severe loss of forests and waterbodies. The reduction of waterbodies adversely affects water safety and the attainment of UN's Sustainable Development Goal 6 regarding the quantity and quality of water. The study also disclosed that the household livelihoods within the catchment were negatively affected by these substantial and far-reaching land cover changes. For effective and sustainable management of land and natural resources, it is important to compensate and involve the local communities in the decisions regarding the management of their catchment.

Author Contributions: P.A.-A., F.K., R.A. and K.O.-D. conceived and designed the research. P.A.-A. and F.K. collected the data, J.H., E.J. and M.N.A. reviewed and commented on the study design and methodology; P.A.-A. and F.K. analysed the data; P.A.-A., F.K., R.A., J.H., K.O.-D., E.J. and M.N.A. co-wrote the paper.

Funding: This research was funded by DANIDA (BSUII-KNUST, GHANA)," and "The APC was funded by the same funder.

Acknowledgments: This research was supported by funding from DANIDA through its Building Stronger Universities (KNUST BSU II) programme. The authors acknowledge the support of participating communities in the study. The authors are also grateful to Anne Mette Poulsen for valuable linguistic assistance and to Mr. Eric Kwabena Asamoah at the Crop Research Institute, Ghana, for his help with the Landsat images.

Conflicts of Interest: The authors declare no conflict of interest. 


\section{Appendix A Appendix}

Table A1. Socio-demographic characteristics of the respondents.

\begin{tabular}{|c|c|c|c|c|c|c|c|}
\hline \multirow{2}{*}{ Variables } & \multicolumn{7}{|c|}{ Community of Respondents } \\
\hline & Bokwankye & Daabaa & Esaase & Nyankyereniase & Ohwim & Owabi & Total \\
\hline \multicolumn{8}{|c|}{ Sex of Respondents } \\
\hline Male & $28(7.0)$ & $23(5.8)$ & $23(5.8)$ & $46(11.5)$ & $38(9.5)$ & $22(5.8)$ & $180(45.0)$ \\
\hline Female & $32(8.0)$ & $37(9.3)$ & $39(9.8)$ & $53(13.3)$ & $41(10.3)$ & $18(4.5)$ & $220(55.0)$ \\
\hline \multicolumn{8}{|c|}{ Age of Respondents } \\
\hline$\leq 18$ years & $8(2.0)$ & $2(0.5)$ & $5(1.3)$ & $7(1.8)$ & $6(1.5)$ & $1(0.3)$ & $29(7.3)$ \\
\hline 19-39 years & $18(4.5)$ & $17(4.3)$ & $35(8.8)$ & $35(8.8)$ & $31(7.8)$ & $15(3.3)$ & $151(37.8)$ \\
\hline $40-59$ years & $24(6.0)$ & $30(7.5)$ & $19(4.8)$ & $35(8.8)$ & $29(7.3)$ & $16(4.0)$ & $153(38.3)$ \\
\hline$\geq 60$ years & $10(2.5)$ & $11(2.8)$ & $3(0.8)$ & $22(5.5)$ & $13(3.3)$ & $8(2.0)$ & $67(16.8)$ \\
\hline \multicolumn{8}{|c|}{ Highest Educational Level } \\
\hline No Formal & $18(4.5)$ & $14(3.5)$ & $23(5.8)$ & $27(6.8)$ & $33(8.3)$ & $9(2.3)$ & $124(31.0)$ \\
\hline Basic & $20(5.0)$ & $18(4.5)$ & $20(5.0)$ & $46(11.5)$ & $16(4.0)$ & $13(3.3)$ & 133 (33.3) \\
\hline Post Basic & $16(4.0)$ & $20(5.0)$ & $12(3.0)$ & $19(4.8)$ & $22(5.5)$ & $15(3.3)$ & $104(26.0)$ \\
\hline Tertiary & $6(1.5)$ & $8(2.0)$ & $7(1.8)$ & $7(1.8)$ & $8(2.0)$ & $3(0.8)$ & $39(9.8)$ \\
\hline \multicolumn{8}{|l|}{ Indigenes } \\
\hline Yes & $40(10.0)$ & $30(7.5)$ & $43(10.8)$ & $57(14.3)$ & 44 (11.0) & $30(7.5)$ & $244(61.0)$ \\
\hline No & $20(5.0)$ & $30(7.5)$ & $19(4.8)$ & $42(10.5)$ & $35(8.8)$ & $10(2.5)$ & $156(39.0)$ \\
\hline \multicolumn{8}{|c|}{ Household Size } \\
\hline $1-5$ & $29(7.3)$ & $40(10.0)$ & $34(8.5)$ & $36(9.0)$ & $43(10.8)$ & $25(6.3)$ & 207 (51.9) \\
\hline $6-10$ & $20(5.0)$ & $18(4.5)$ & $15(3.3)$ & $32(8.0)$ & $27(6.8)$ & $15(3.3)$ & $127(31.8)$ \\
\hline$>10$ & $11(2.8)$ & $2(0.5)$ & $13(3.3)$ & $31(7.8)$ & $9(2.3)$ & $0(0.0)$ & $66(16.5)$ \\
\hline Total & $60(15.0)$ & $60(15.0)$ & $62(15.5)$ & $99(24.8)$ & 79 (19.8) & $40(10.0)$ & $400(100)$ \\
\hline
\end{tabular}

Numbers in parentheses are percentages and those outside are the respondent sums. 


\section{References}

1. Tilman, D.; Fargione, J.; Wolff, B.; D'Antonio, C.; Dobson, A.; Howarth, R.; Schindler, D.; Schlesinger, W.; Simberloff, D.; Swackhamer, D. Forecasting agriculturally driven global environmental change. Science 2001, 292, 281-284. [CrossRef]

2. Xu, C.; Liu, M.; An, S.; Chen, J.; Yan, P. Assessing the impact of urbanization on regional net primary productivity in Jiangyin County, China. J. Environ. Manag. 2007, 85, 597-606. [CrossRef]

3. Intergovernmental Panel on Climate Change. Climate Change 2001: Impacts, Adaptation, and Vulnerability. Contribution of Working Group II to the Third Assessment Report of the Intergovernmental Panel on Climate Change; Cambridge University Press: Cambridge, UK, 2001.

4. Foley, J.A.; DeFries, R.; Asner, G.P.; Barford, C.; Bonan, G.; Carpenter, S.R.; Chapin, F.S.; Coe, M.T.; Daily, G.C.; Gibbs, H.K. Global consequences of land use. Science 2005, 309, 570-574. [CrossRef]

5. Lambin, E.F.; Meyfroidt, P. Land use transitions: Socio-ecological feedback versus socio-economic change. Land Use Policy 2010, 27, 108-118. [CrossRef]

6. Kleeman, J.; Baysal, G.; Bulley, H.N.N.; Furst, C. Assessing driving forces of land use and land cover change by a mixed-method approach in North-Eastern Ghana, West Africa. J. Environ. Manag. 2017, 196, 411-442. [CrossRef]

7. Prakasam, C. Land use and land cover change detection through remote sensing approach: A case study of Kodaikanal taluk, Tamil nadu. Int. J. Geomat. Geosci. 2010, 1, 150.

8. Turner, B.L.; Meyer, W.B. Global land use and land cover change: An overview. In Changes in Land Use and Land Cover: A Global Perspective; Meyer, W.B., Turner, B.L., Eds.; Cambridge University Press: Cambridge, UK, 1994.

9. Vitousek, P.M.; Mooney, H.A.; Lubchenco, J.; Melillo, J.M. Human domination of earth's ecosystem. Science 1997, 277, 494-499. [CrossRef]

10. Otter, L.; Olago, D.O.; Niang, I. Global Change Processes and Impacts in Africa: A Synthesis; East African Publishers: Portsmouth, UK, 2007; pp. 109-130.

11. Antwi-Agyei, P.; Dougill, A.J.; Fraser, E.D.G.; Stringer, L.C. Characterising the nature of household vulnerability to climate variability: Empirical evidence from two regions of Ghana. Environ. Dev. Sustain. 2013, 15, 903-926. [CrossRef]

12. Thompson, J.; Scoones, I. Addressing the dynamics of agri-food systems: An emerging agenda for social science research. Environ. Sci. Policy 2009, 12, 386-397. [CrossRef]

13. Antwi-Agyei, P.; Fraser, E.D.; Dougill, A.J.; Stringer, L.C.; Simelton, E. Mapping the vulnerability of crop production to drought in Ghana using rainfall, yield and socioeconomic data. Appl. Geogr. 2012, 32, 324-334. [CrossRef]

14. Thornton, P.K.; Jones, P.G.; Ericksen, P.J.; Challinor, A.J. Agriculture and food systems in sub-Saharan Africa in a 4 C+ world. Philos. Trans. R. Soc. 2011, 369, 117-136. [CrossRef]

15. Chambers, R.; Conway, G. Sustainable Rural Livelihoods: Practical Concepts for the 21st Century. IDS Discussion Paper No. 296; Institute of Development Studies: Brighton, UK, 1992.

16. Ellis, F. Rural Livelihoods and Diversity in Developing Countries; Oxford University Press: Oxford, UK, 2000.

17. Kamwi, J.M.; Chirwa, W.P.C.; Manda, S.O.M.; Graz, P.F.; Kätsch, C. Livelihoods, land use and land cover change in the Zambezi Region, Namibia. Popul. Environ. 2015, 37, 207-230. [CrossRef]

18. UNDP. Sustainable Development Goals. Available online: http://www.undp.org/content/undp/en/home/ sdgoverview/post-2015-development-agenda.html (accessed on 10 March 2018).

19. Gosling, S.N.; Arnell, N.W. Simulating current global river runoff with a global hydrological model: Model revisions, validation, and sensitivity analysis. Hydrol. Process. 2011, 25, 1129-1145. [CrossRef]

20. Boadi, N.O.; Borquaye, L.S.; Darko, G.; Wemegah, D.D.; Agorsor, D.; Akrofi, R. Assessment of the quality of the Owabi reservoir and its tributaries. Cogent Food Agric. 2018, 4, 1492360. [CrossRef]

21. Akoto, O.; Abankwa, E. Evaluation of Owabi reservoir (Ghana) water quality using factor analysis. Lakes Res. Res. Manag. 2014, 19, 174-182. [CrossRef]

22. Agyen-Brefo, R. The Effects of Encroachment on Sustainable Public Land Management: A Case Study of the Owabi Catchment Area in Kumasi. Master's Thesis, Kwame Nkrumah University of Science and Technology, Kumasi, Ghana, 2012. 
23. Akoto, O.; Bruce, T.N.; Darko, G. Heavy metals pollution profiles in streams serving the Owabi reservoir. Afr. J. Environ. Sci. Technol. 2008, 2, 354-359.

24. Nunoo, J.; Agbo, N.; Ackah, M. Fish fauna of the Owabi Dam Reservoir in Ghana. Proceedings of the Inter. Acad. Ecol. Environ. Sci. 2012, 2, 21-26.

25. Ameyaw, Y.; Dapaah, G.S. The effect of encroachment on ecosystem services provided by the Owabi Wetlands and Wildlife. Int. J. Environ. Sci. Nat. Res. 2017, 1, 555628. [CrossRef]

26. Kumasi, T.C.; Obiri-Danso, K.; Ephraim, J.H. Community engagement in the sustainable management of rivers: Barekese catchment, Kumasi, Ghana. Environ. Dev. Sustain. 2010, 12, 927-943. [CrossRef]

27. Yaro, J.A. Customary tenure systems under siege: Contemporary access to land in Northern Ghana. GeoJournal 2010, 75, 199-214. [CrossRef]

28. Republic of Ghana. Emerging Lands Tenure Issues; Ministry of Lands and Forestry: Accra, Ghana, 2003.

29. Antwi-Agyei, P.; Dougill, A.J.; Stringer, L.C. Impacts of land tenure arrangements on the adaptive capacity of marginalized groups: The case of Ghana's Ejura Sekyedumase and Bongo districts. Land Use Policy 2015, 49, 203-212. [CrossRef]

30. Atwima Nwabiagya District Assembly. Update of Annual Progress Report the District for 2014; Atwima Nwabiagya District Assembly, Ghana Statistical Service: Accra, Ghana, 2014.

31. Van der Geest, K. We're Managing Climate Change and Livelihood Vulnerability in Northwest Ghana; African Studies Centre: Leiden, The Netherlands, 2004.

32. Bryman, A.; Teevan, J.J. Social Research Methods. Canadian Edition, Ontario; Oxford University Press: Oxford, UK, 2005.

33. Boakye, E.; Odai, S.N.; Adjei, K.A.; Annor, F.O. Landsat images for assessment of the impact of land use and land cover changes on the Barekese Catchment in Ghana. Eur. J. Sci. Res. 2008, 22, 269-278.

34. Frimpong, A. Application of Remote Sensing and GIS for Forest Cover Change Detection. (A Case Study of Owabi Catchment in Kumasi, Ghana). Master's Thesis, Kwame Nkrumah University of Science and Technology, Kumasi, Ghana, 2011.

35. Akoto, O.; Gyamfi, O.; Darko, G.; Barnes, V.R. Changes in water quality in the Owabi water treatment plant in Ghana. Appl. Water Sci. 2017, 7, 175-186. [CrossRef]

36. Appiah, D.O.; Forkuo, E.K.; Bugri, J.T.; Apreku, T.O. Geospatial analysis of land use and land cover transitions from 1986-2014 in a peri-urban Ghana. Geosciences 2017, 7, 125. [CrossRef]

37. Addo-Fordjour, P.; Ankomah, F. Patterns and drivers of forest land cover changes in tropical semi-deciduous forests in Ghana. J. Land Use Sci. 2016, 12, 71-86. [CrossRef]

38. Ogechi, B.A.; Waithaka, E.H. Land use land cover changes and implications for food production: A case study of Keumbu Region Kisii County, Kenya. In Proceedings of the Scientific Conference Proceedings, Washington, DC, USA, 19 May 2017.

39. Ghana Statistical Service. Population and Housing Census; Summary of Final Results; GSS: Accra, Ghana, 2010; p. 102.

40. Ghana Statistical Services, Urbanisation. 2010 Population and Housing Census; Ghana Government: Accra, Ghana, 2014.

41. Antwi, E.K.; Boakye-Danquah, J.; Asabere, S.B.; Yiran, G.A.; Loh, S.K.; Awere, K.G.; Owusu, A.B. Land Use and Landscape Structural Changes in the Ecoregions of Ghana. J. Dis. Res. 2014, 9, 452-467. [CrossRef]

42. Attua, E.M.; Fisher, J.B. Historical and future land-cover change in a municipality of Ghana. Earth Interact. 2011, 15, 1-26. [CrossRef]

43. Oduro, C.Y.; Ocloo, K.; Peprah, C. Analyzing Growth Patterns of Greater Kumasi Metropolitan Area Using GIS and Multiple Regression Techniques. J. Sustain. Dev. 2014, 7, 13-31. [CrossRef]

44. Cobbinah, P.B.; Amoako, C. Urban sprawl and the loss of peri-urban land in Kumasi, Ghana. Int. J. Soc. Hum. Sci. 2012, 6, 388-397.

45. Asubonteng, K.; Pfeffer, K.; Ros-Tonen, M.; Verbesselt, J.; Baud, I. Effects of tree-crop farming on land-cover transitions in a mosaic landscape in the eastern region of Ghana. Environ. Manag. 2018, 62, 529-547. [CrossRef]

46. Adade, B.; Oppelt, N. Land-use/land-cover change analysis and urban growth modelling in the Greater Accra Metropolitan Area (GAMA). Ghana. Urban Sci. 2019, 3, 26. [CrossRef]

47. Shoyama, K.; Braimoh, A.K.; Avtar, R.; Saito, O. Land Transition and Intensity Analysis of Cropland Expansion in Northern Ghana. Environ. Manag. 2018, 62, 892-905. [CrossRef] 
48. Kufuor, K.O. Forest management in Ghana: Towards a sustainable approach. J. Afr. Law 2000, 44, 52-64. [CrossRef]

49. Kassa, H.; Dondeyne, S.; Poesen, J.; Frankl, A.; Nyssen, J. Transition from forest-based to cereal-based agricultural systems: A review of the drivers of land use change and degradation in Southwest Ethiopia. Land Degrad. Dev. 2017, 28, 431-449. [CrossRef]

50. Hamza, I.A.; Iyela, A. Land use pattern, climate change, and its implication for food security in Ethiopia: A review. Ethiop. J. Environ. Stud. Manag. 2012, 5, 26-31. [CrossRef]

51. Hilson, G.; Nyame, F. Gold mining in Ghana's forest reserves: A report on the current debate. Area 2006, 38, 175-185. [CrossRef]

52. Badu, M.; Wemegah, D.D.; Boadi, N.O.; Brown, F.A. Assessment of the nutrient load and selected heavy metals in the Owabi reservoir and its feeder waters. Am. J. Ind. Res. 2013, 4, 333-343.

53. Babatunde, R.O.; Qaim, M. Impact of off-farm income on food security and nutrition in Nigeria. Food Policy 2010, 5, 303-311. [CrossRef]

54. Paavola, J. Livelihoods, vulnerability and adaptation to climate change in Morogoro, Tanzania. Environ. Sci. Policy 2008, 11, 642-654. [CrossRef]

55. Antwi-Agyei, P.; Quinn, C.H.; Adiku, S.G.K.; Codjoe, S.N.A.; Dougill, A.J.; Lamboll, R.; Dovie, D.B.K. Perceived stressors of climate vulnerability across scales in the Savannah Zone of Ghana: A participatory approach. Reg. Environ. Chang. 2016, 17, 213-227. [CrossRef]

56. Antwi-Agyei, P.; Dougill, A.J.; Stringer, L.C.; Codjoe, S.N.A. Adaptation opportunities and maladaptive outcomes in climate vulnerability hotspots of northern Ghana. Clim. Risk Manag. 2018, 19, 83-93. [CrossRef]

57. Kumasi, T.C.; Obiri-Danso, K.C.; Ephraim, J. Impacts of land-use change on the water quality of the main source of pipe borne water for Kumasi, Ghana (a case study of the Barekese reservoir catchment). In Proceedings of the Conference on Water Management Challenges in Global Change, Leicester, UK, 1-18 December 2017; pp. 243-248.

58. Owusu, V.; Abdulai, A.; Abdul-Rahma, S. Non-farm work and food security among farm households in Northern Ghana. Food Policy 2011, 36, 108-118. [CrossRef]

59. Obiaw, E. Intitutional framework for CFCs towards forest management. In Proceedings of the Refresher Course for CFCs and CBAGs in Eastern, Ashanti and Brong Ahafo Region, Kumasi, Ghana, 11-13 May 2010.

60. Ostrom, E. Governing the Commons: The Evolution of Institutions for Collective Action; Cambridge University Press: Cambridge, UK, 1990. 